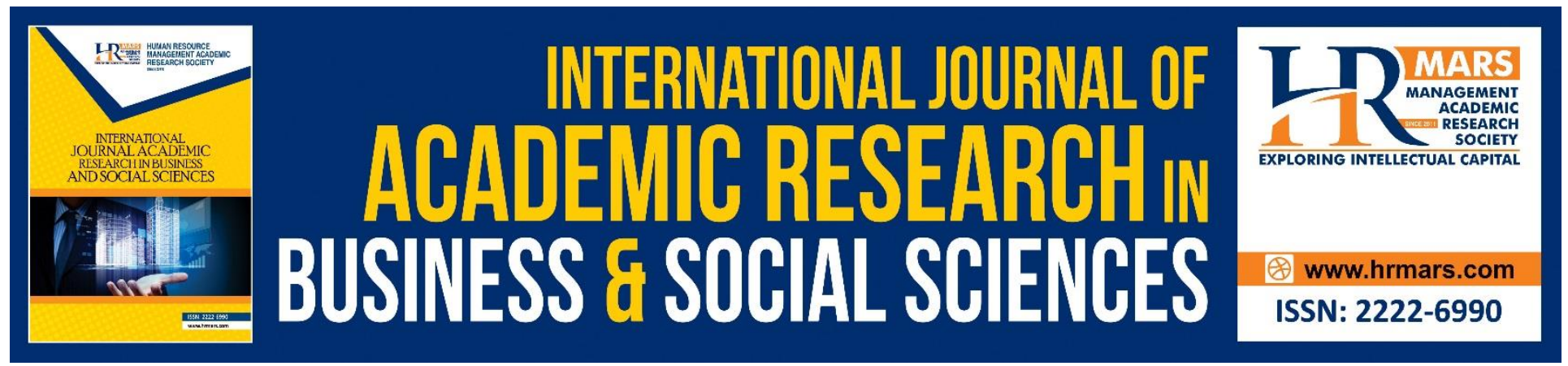

\title{
Impact of SERVQUAL model dimensions for Customer Satisfaction towards Vehicle Leasing Providers in Sri Lanka
}

\author{
Pathirana, U.P.G.Y
}

To Link this Article: http://dx.doi.org/10.6007/IJARBSS/v9-i1/5512 DOI: 10.6007/IJARBSS/v9-i1/5512

Received: 21 Dec 2018, Revised: 19 Jan 2019, Accepted: 04 Feb 2019

Published Online: 12 Feb 2019

In-Text Citation: (Pathirana, 2019)

To Cite this Article: Pathirana, U. P. G. . (2019). Impact of SERVQUAL model dimensions for Customer Satisfaction towards Vehicle Leasing Providers in Sri Lanka. International Journal of Academic Research in Business and Social Sciences, 9(1), 1075-1085.

Copyright: (C) 2019The Author(s)

Published by Human Resource Management Academic Research Society (www.hrmars.com) This article is published under the Creative Commons Attribution (CC BY 4.0) license. Anyone may reproduce, distribute, translate and create derivative works of this article (for both commercial and non-commercial purposes), subject to full attribution to the original publication and authors. The full terms of this license may be seen at: http://creativecommons.org/licences/by/4.0/legalcode

$$
\text { Vol. 9, No. 1, 2019, Pg. } 1099 \text { - } 1110
$$

Full Terms \& Conditions of access and use can be found athttp://hrmars.com/index.php/pages/detail/publication-ethics 


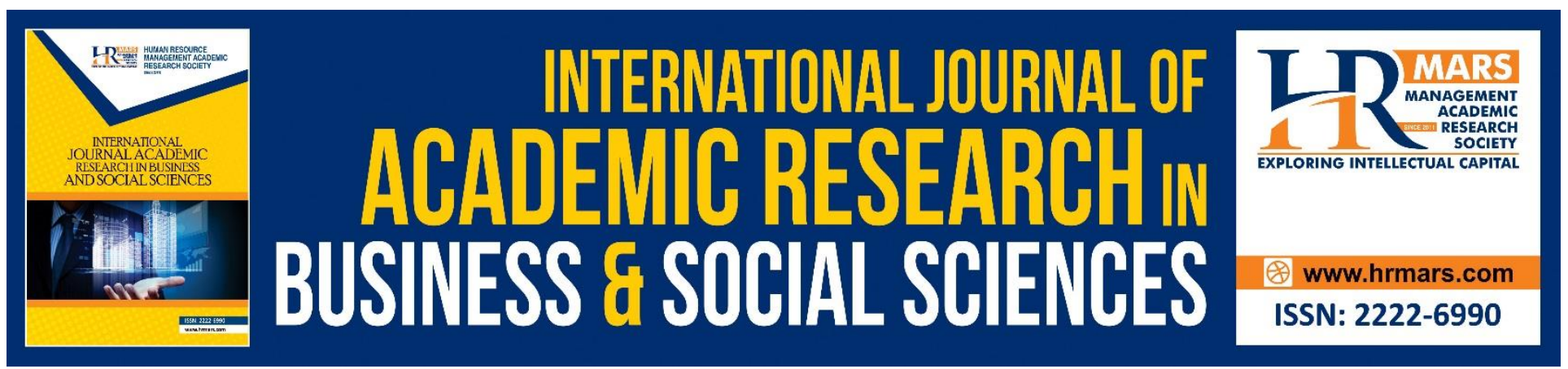

\title{
Impact of SERVQUAL Model Dimensions for Customer Satisfaction towards Vehicle Leasing Providers in Sri Lanka
}

\author{
Pathirana U.P.G.Y \\ Academic Instructor, Department of Business Management, Faculty of Business \\ Sri Lanka Institute of Information Technology, New Kandy Road, Malabe \\ Email: Geethma.p@sliit.lk
}

\begin{abstract}
Vehicle leasing providers plays a big role in automobile buying and selling. Science vehicle leasing is coming under the service category customer satisfaction can be access through the quality of service provided by vehicle leasing providers. So in order to understand this SERQUAL model was used. So in order to reach research objectives data was gathered though a questionnaire with a sample of 100 recent customers of vehicle leasing service providers. From the data analysis it was found that customers are moderately satisfied about the service they are receiving and there is a positive relationship in between customer satisfaction and service quality which indicates that there is a high impact of responsiveness for the service quality.
\end{abstract}

Keywords: Customer Satisfaction, Service Quality, Relationship

\section{Background of the Study}

Buying a vehicle is one of the main necessities for most of the people in modern society due to various reasons. When a person wants to buy a vehicle they may not be capable of paying full amount of the vehicle. In a situation like that most people are going for vehicle loans or vehicle leasing facilities. Most Sri Lankan customers prefer of getting leasing facility rather than going for a vehicle loan due to reasons like availability of many choices and due to different facilities provided by those leasing providers. When it comes to history of Sri Lanka Leasing industry first company was established in Sri Lanka in 1980 with Orix leasing company as a joint venture according to the recommendations of World Bank. According to government regulations leasing activities can be undertaken by Banks, Registered finance companies and by Registered Leasing companies (Articles on Leasing, 2008 ).At present there are around 48 leasing facility providers in Sri Lanka (Registered Finance Leasing Establishments, 2018).Science leasing providers are coming under service sector companies have to focus on service quality dimensions affecting towards customer satisfaction. According to few 
INTERNATIONAL JOURNAL OF ACADEMIC RESEARCH IN BUSINESS AND SOCIAL SCIENCES

Vol.9,No. 1, Jan, 2019,E-ISSN:2 22 2-6990 @ 2019 HRMARS

discussions done with recent leasing customers in Sri Lanka it seems that they are not much satisfy about the service quality of Sri Lankan leasing providers.

\section{Research Problem}

Many researchers have conducted their researches in order to identify service quality dimensions affecting for different types of service sectors. One of the main reasons for this is that quality of services provided by different service providing organizations is affecting for factors like customer satisfaction and customer retention (Zengmo, Laimpreecha, \& Chemsripong, 2015 ).When considering about very sensitive services like financial and banking services quality of the service provided plays a very curtail factor. In banking sector customer satisfaction and customer loyalty depends on the quality of services provided by financial institutes (Ahmed, Ahmad, \& Jan, 2016). Managing quality of the service provided by service sector organizations are very important for them in order to reach short term as well as long term goals of the organization. When it applies with service quality dimension this dimension changes according to the type of the service provided by each organization. When it comes to restaurants customers are measuring the quality of the service that they are going to receive thought the appearance or the tangibility of the restaurant (Aftab \& Sarwar, 2016).

When it comes to Sri Lankan context a study was conducted in order to identify the impact of service quality towards customer satisfaction in hospitals in Jaffna district. According to the study it was found that service quality and customer satisfaction is positively correlated according to the study (Sritharan \& Velnampy, 2011).

According to the statistics of Transportation and civil aviation in Sri Lanka form 2012 to 2017 vehicle transfers increased up to 708,201 (Aviation, 2019). From the data available in Central Bank report of 2018 it was observed that there are around 48 leasing providing companies in Sri Lanka (Registered Finance Leasing Establishments, 2018).These 48 leasing providers are coming under another three categories. Banks are one category among them. Those banks can be categorized in to two sessions as Licensed Commercial Banks some examples for these are Bank of Ceylon,Amana Bank and Cargills bank. The other category is Licensed Specialized Banks.Lanka puthra development bank and National Savings Bank is some examples for this category.Registeredfinance companies are another category AbansFinance,AllianceFinance,Arpico Finance and Central finance are companies under this category. The last category is registered leasing companies. Mercantile Investment, soft logic finance and people leasing finance are some registered leasing companies established in Sri Lanka.

So when considering about the services provided by all these categories of companies the quality of services provided by them is affecting in different ways for the organization. The main impacts of service quality is affecting for customer satisfaction and for customer retention (Ahmed, Ahmad, \& Jan, 2016). When it comes to Sri Lankan context customers those who receive services of leasing companies are not much satisfied about the service that they received. According to the discussions conducted with recent service receivers leasing companies' issues with these areas in leasing companies were identified. Taking too much time in processing the leasing, Changing rates and deposit amount time to time and unavailability of company representatives are some issues they mentioned. In order to identify the impact of service quality towards customer satisfaction SERVQUAL model was used in the study. 
INTERNATIONAL JOURNAL OF ACADEMIC RESEARCH IN BUSINESS AND SOCIAL SCIENCES

Vol.9,No. 1, Jan, 2019,E-ISSN:2 22 2-6990 @ 2019 HRMARS

According to those problems identified in leasing sector this study mainly focus about identifying service quality dimension affecting for customer satisfaction towards leasing providers in Sri Lanka.

\section{Research Objectives \\ Main Objective}

- To identify the service quality dimensions affecting for customer satisfaction towards vehicle leasing providers in Sri Lanka.

In order to identify service quality dimensions wh8ich are affecting for customer satisfaction SERVQUAL model was used. Under this model independent variables such as, Tangibility, Assurance, Reliability Responsiveness and Empathy was used.

\section{Sub Objectives}

- To understand the level of customer satisfaction towards vehicle leasing providers in Sri Lanka.

- To identify the most influential service quality dimension affecting towards customer satisfaction.

\section{Literature Review}

Many researchers have conducted their studies in the field of service quality and customer satisfaction in different sectors.

\section{Customer Satisfaction}

Customer satisfaction basically means how far the organization was capable of meeting customer expectations. Having well satisfied customers the organization helps to gain many advantages towards the organization. After identifying this many researchers have conducted their studies in order to study about this further. When any organization is capable of satisfying their customers they can gain more profits towards the organization. Also the same study which was conducted in related to the real estate industry reveals that when customers perceive that they are receiving a quality service from the organization they are more retaining with the organization which leads to long term success and profitability (Preko, Feglo, \& Agbanu, 2014 ).According to a study conducted in Pakistan Housing service providing case study it was revealed that customers are satisfied about the service they are receiving related to the housing facility given to them. They believe that they are satisfied about the service they are receiving due to the efficiency. Also they believe the service is efficient as it is provided by the government (Khan, Batool, \& Hussain, 2015 ).So it shows that customer satisfaction is helping for organizations to increase profits and retain more customers within the organization. Especially when it comes to service providing organizations customer satisfaction is very important in order to attract and retain customers.

\section{SERVQUAL Model}

SERVQUAL model was introduced by American Marketing guru in order to understand the factors affecting for quality of service. This model is important to measure the difference between perceived expectations and actual performances of the services received by the customers. Using this model helps to gain many advantages towards the organization. This model helps to compare yearly 
performances, to determine how service improvements have affected customers' perceptions and expectations of the service over time and to determine the effectiveness of service development and improvement initiatives in targeted dimension (Shahin, 2013). When considering about this model it was supposed that this model provides a useful framework to measure quality of services. Th8is model was built different types of service encounters and the model was rebuilt with new situations and the modeling was based on new concepts and it has considered about new variable situations and existing models (Seth, Deshmukh, \& Vrat, 2004 ). When considering about the dimensions of SERVQUAL model it was found that there are mainly three aspects related to the service quality of an organization. They are physical elements, people elements and process elements. Tangibles, physical aspects,and physical service environment are related to the Physical Environment element with regard to the service quality. Reliability, problem solving, outcome quality are related to Process element of SERQUAL model (Yarimoglu1, 2014). These service quality dimension are affecting for different types of sectors in different manners. When considering about retailing customers have high expectations Customers have highest expectations on the promptness of service, accuracy of transactions, security issues and concerns. When it comes to the same situation customers have lower expectations regarding cleanliness, ambience. Customers are highly satisfied if they are getting a service with a good speed (Naik, Gantasala, \& Prabhakar, 2010 ).

Further some researchers have found that SERQUAL dimensions are affecting for customer retention and customer satisfaction. According to a study conducted in related to the logistics sector it was found that service quality does act as an important predictor for customer satisfaction and customer loyalty in logistics. Further this study has found that readiness to

Recommend, retention and word of mouth need are arising due to the service quality of the organization (Ismail \& Yunan, 2016).

So many researchers have focused their attention towards SERVQUAL model related to service quality dimension and its impacts but there are less or few studies conducted in related to finance or leasing sector.

\section{Methodology}

The study applied a quantitative survey design guided by five hypotheses. A conceptual framework has been developed to address the research questions on the basis of a literature review. The study is based on a sample of recent customers from different leasing providers, and it will present results of factor analytics and correlational, descriptive and regression analyses. This study was adopted from Parasuraman's SERVQUAL dimensions. 


\section{Conceptual Framework}

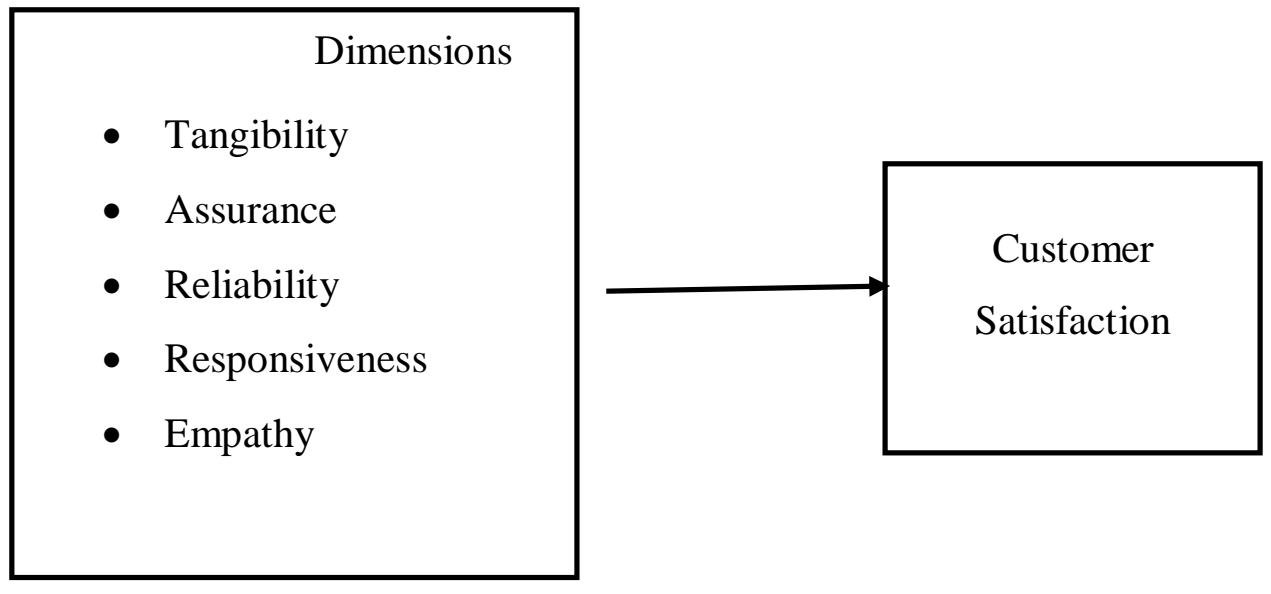

Figure 1-Conceptual Framework

\section{Research Hypothesis}

$\mathrm{H} 1$ : There is a positive relationship between tangibility and customer satisfaction

$\mathrm{H} 2$ : There is a positive relationship between assurance and customer satisfaction

$\mathrm{H} 3$ : There is a positive relationship between reliability and customer satisfaction

$\mathrm{H} 4$ : There is a positive relationship between responsiveness and customer satisfaction

$\mathrm{H} 5$ : There is a positive relationship between empathy and customer satisfaction

The dependent variable of this study is customer satisfaction. This study used five dimensions to measure student satisfaction as mentioned above. An independent variable is a variable that is expected to influence the dependent variable. In the study, service quality dimensions are the independent variables.

Data for the study was collected through primary and secondary sources.

In this research, the quantitative research design will be used applying Likert scale to measure the variables, which will be developed a self-administrated questionnaire in order to determine current levels of customers ' satisfaction and engagement issues concerning increased competition among leasing service providers with various aspects of service quality. To answer the identified research questions, the researcher used the variables based on SERVQUAL factors, which are tangibles, empathy, reliability, responsiveness and assurance supported by the study of (HishamuddinFitri Abu Hasan, 2008)

In order to measure level of customer satisfaction two questions was included in the questionnaire. Which is allocated to measure dependent variable of the study. In order to measure independent variables of the study dimensions of SERVQUAL model was used. Under independent variable five dimensions were identified. In order to measure reliability of the service quality three questions were allocated and in order to measure assurance two questions were used. And also in order to measure empathy four questions were used and to measure reliability three questions were used.

Proposed five dimensions of service quality as follows; 
1. Tangibles: the equipment, physical facilities and appearance of personnel.

2. Empathy: The provision of caring and individualized attention to customers.

3. Reliability: The ability to perform the desired service dependably, accurately and consistently.

4. Responsiveness: The willingness to provide prompt service and help customers.

5. Assurance: Employees courtesy, knowledge and ability to convey trust and confidence.

The population of the study s recent customers of vehicle leasing providers. The most leading and long-standing vehicle leasing providers in Colombo city were selected for the study. Used convenience sampling, the sample in this study was conducted by using 100 customers from vehicle leasing providers.

In this research study, secondary data was gathered using past records of the particular institutes, government statistics relevant to the research area which will gain better understanding on the topic consequently.

\section{Data Analysis}

After collecting the required data, analyze was done by the SPSS data tool which can be used to process the questionnaires, report them in tables and graphs and analyze through regression analysis.

\section{Validity and Reliability}

The internal consistency of the research instrument should be confirmed by reliability analysis Ndubisi (2006). The validity of the questionnaire was acquired according to previous validated studies in which questions will be chosen according to the most suitability to the study. The reliability of the study will be measured by applying pre-test method, Further, evidence to support construct validity and reliability of all survey based scales measuring the key variables will be used as the various services provided correlated significantly with student satisfaction levels to meet up the statistical predictors which the researcher will produce as the ultimate goal of this study.

\section{Data Analysis and Discussion \\ Reliability}

Reliability test was conducted in order to test the consistency of the instrument used in data gathering. In order to measure reliability croanbach alpha was considered.

\begin{tabular}{|l|l|}
\hline Variable Name & Cronbach Alpha Value \\
\hline Reliability & .904 \\
\hline Assurance & .754 \\
\hline Empathy & .655 \\
\hline Responsiveness & .874 \\
\hline Tangibility & .852 \\
\hline Customer Satisfaction & .924 \\
\hline
\end{tabular}




\section{Table 1-Reliability Statics of Dependent and Independent Variable}

If a dimension is having reliability value as 1 that is considered as better reliability and if the cronbach alpha value is less than 0.60 it is considered as poor and if it's in between 0.06 and 0.07 it is considered as acceptable (Sekaran, 2003 ).According to the reliability of the data set customer satisfaction is having the highest cronbach value which is 0.924 and from independent variables reliability is having the highest value which is 0.904 . Science all the dimensions are having a value in between 0.60 and 0.70 tit can consider as a reliable data set.

\section{Characteristics of Sample}

The demographic criteria's of the study was identified thorough questions related to gender, age, type of employment and related working sector. The sample of the study was based on recent customers from various vehicle leasing providers in Sri Lanka. The data was collected by using a sample of 100 customers. From the sample studied $77.6 \%$ are male and $22.4 \%$ are female customers. When considering about age most people of the sample was in the age level of 35-44 which is representing $32.7 \%$.Least were more than 55 years. Also the study considered about the working sector of each respondents of the sample. According to the respondents of the sample it was found that most are in permanent employment category and entrepreneurs.

\section{Analysis of Satisfaction Level}

In order to measure satisfaction level of customers related to the service that they received one sample T-test was conducted. When using one sample T-test following criteria's were used.

- If Satisfaction <3, then Customer Satisfaction level is low

- If Satisfaction=3, then Customer Satisfaction level is moderate

- If Satisfaction>3, then Customer Satisfaction level is high

When considering about the output of the one sample T-test the value was 2.92 ,Science the value is more closer to 3 this shows customer satisfaction towards vehicle leasing providers are moderate.

\section{Correlation Analysis}

Correlation analysis is a statistical method using in order to measure the fluctuation of two variables. Correlation is measured using " $r$ " value. This " $r$ " value can be both negative and positive (Zaid, 2015)

In order to measure the fluctuation among these independent and dependent variables correlation analysis was conducted for the study.

\begin{tabular}{|l|l|}
\hline Variable & R value \\
\hline Assurance & 0.829 \\
\hline Tangibility & 0.726 \\
\hline Reliability & 0.629 \\
\hline Responsiveness & 0.883 \\
\hline Empathy & 0.838 \\
\hline
\end{tabular}

Table 2-Correlation Analysis

According to all the $\mathrm{R}$ values of analyzed it was found that all the independent variables are positively correlated with dependent variable. This indicates that there is a positive relationship in between 
INTERNATIONAL JOURNAL OF ACADEMIC RESEARCH IN BUSINESS AND SOCIAL SCIENCES

Vol.9,No. 1, Jan, 2019,E-ISSN:2 22 2-6990 ¿ 2019 HRMARS

customer satisfaction and service quality dimensions towards leasing providers. From this all five independent variables Responsiveness and Empathy has the most significant impact from this al variables.

\section{Regression Analysis}

Regression analysis is used in order to understand how much of total variance in dependent variable can explain by the independent variable. So in regression analysis beta value was used in order to find the impact of independent variable towards the dependent variable.

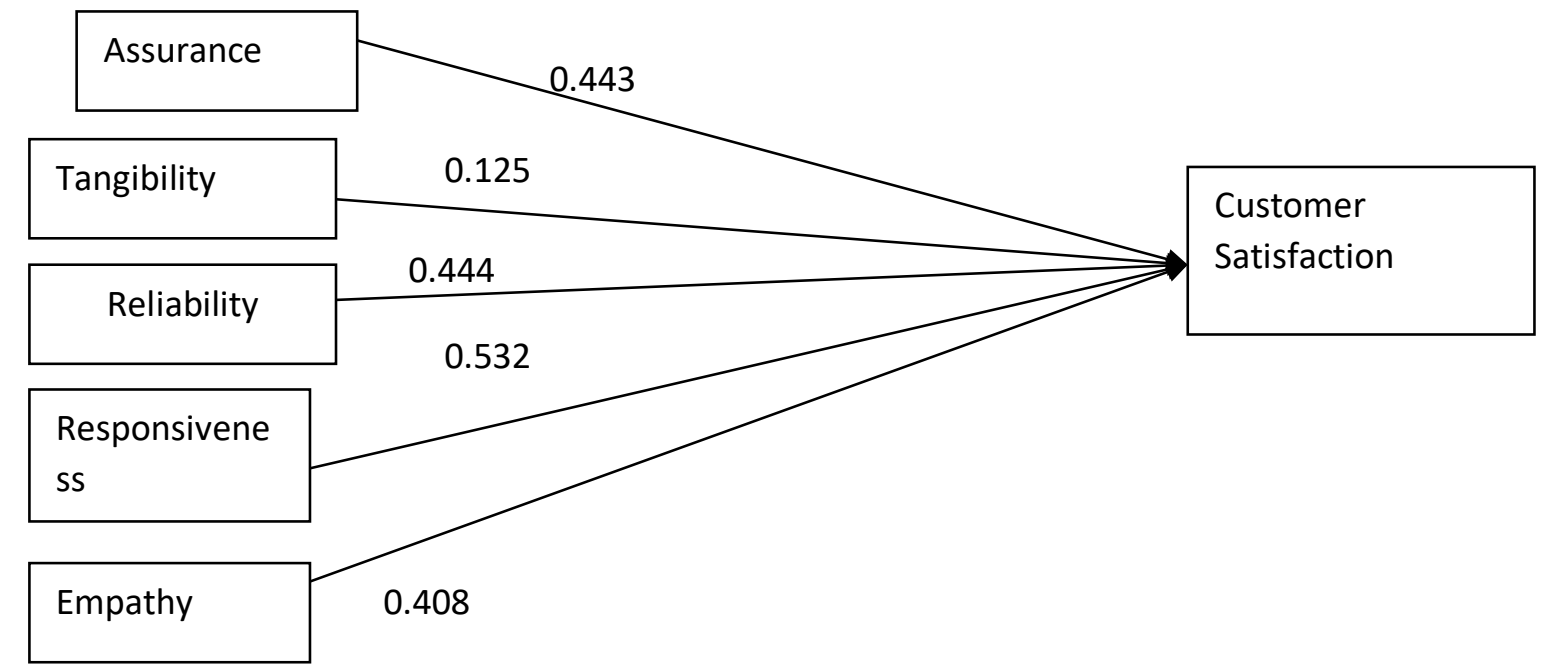

Figure 2-Conceptual Framework with beta Value

The regression analysis indicates that responsiveness is having the strongest relationship with the customer satisfaction while tangibility is having the weakest relationship with the dependent variable.

\section{Hypothesis Testing}

Hypothesis testing was conducted based on correlation and regression analysis. According to the results of the regression analysis all independent variables are positively correlated with the dependent variable. 
INTERNATIONAL JOURNAL OF ACADEMIC RESEARCH IN BUSINESS AND SOCIAL SCIENCES Vol.9,No. 1, Jan, 2019,E-ISSN:2 22 2-6990 @ 2019 HRMARS

\begin{tabular}{|l|l|}
\hline Hypothesis & Accepted/rejected \\
\hline $\begin{array}{l}\text { H1:There is a positive relationship between } \\
\text { tangibility and customer satisfaction }\end{array}$ & Accepted \\
\hline $\begin{array}{l}\text { H2: There is a positive relationship between } \\
\text { assurance and customer satisfaction }\end{array}$ & Accepted \\
\hline $\begin{array}{l}\text { H3: There is a positive relationship between } \\
\text { reliability and customer satisfaction }\end{array}$ & Accepted \\
\hline $\begin{array}{l}\text { H4: There is a positive relationship between } \\
\text { responsiveness and customer satisfaction }\end{array}$ & Accepted \\
\hline $\begin{array}{l}\text { H5: There is a positive relationship between } \\
\text { empathy and customer satisfaction }\end{array}$ & Accepted \\
\hline
\end{tabular}

Table 3-Hypothesis Testing

So these shows the entire five hypotheses were accepted. This shows that there is a positive relationship in between customer satisfaction and service quality dimensions of SERVQUAL model.

\section{Conclusion and Recommendations Conclusion}

So this study was focused on understanding the impact of dimensions of service quality towards customer satisfaction towards vehicle leasing providers in Sri Lanka. According to the dimensions of SERVQUAL model the study was conducted. The study was conducted according to the responses of recent customers of vehicle leasing companies. Correlation and regression analysis was conducted in order to reach the desired aims of the study. According to the results of the correlation analysis it was found that all the independent variables are positively correlated with the dependent variable. And regression analysis was conducted in order to understand the level of impact on independent variable towards the dependent variable. The regression analysis of the study concluded as responsiveness is the most impacting independent variable towards the dependent variable of the study while tangibility indicated the least impacting factor affecting for customer satisfaction in vehicle leasing providers in Sri Lanka. Also the study focused on finding the level of satisfaction towards vehicle leasing providers in Sri Lanka, which finding concludes that customers are moderately satisfied about the vehicle leasing providers.

The results of this study helps for vehicle leasing providers' in order to maintain the good quality of the service in order to increase satisfaction level of customers. This level of satisfaction helps for companies to attract new customers towards the organization and also to retain current customers in the organization.

\section{Future Research}

The study was basically focused on financial sector of Sri Lanka. And from that vehicle leasing providers' service quality and customer satisfaction was studied. Future researchers can focus another service area of this such as vehicle insurance providers. Other than this they can focus on another dependent variable such as customer retention and recommendation. 
INTERNATIONAL JOURNAL OF ACADEMIC RESEARCH IN BUSINESS AND SOCIAL SCIENCES

Vol.9,No. 1, Jan, 2019,E-ISSN:2 22 2-6990 @ 2019 HRMARS

\section{Limitations}

When conducting the research the researcher had to face few limitations.

1. Difficulty in taking contact details of recent vehicle leasing customers,

2. Inability to collect data from a large geographical area.

\section{Managerial Implications}

According to the outcome of the study it was found that there is a positive relationship in between service quality dimensions and customer satisfaction towards vehicle leasing providers in Sri Lanka. The regression analysis concluded that responsiveness has the most impact for customer satisfaction. So the leasing providers should focus on increasing responsiveness of their service other than investing large amount of money for tangibility which is having the least impact.

\section{References}

1. Ahmed, S., Ahmad, K., \& Jan, T. (2016). The impact of service quality on customer satisfaction and customer loyalty:An empirical study on Islamic banks in Bahrain. Journal of Islamic Thought and and Civilization of International Islamic University of Malaysis , 261-281.

2. Articles on Leasing. (2008). Retrieved January 29, 2019, from Vinod Kothari Consultants: http://vinodkothari.com/leasing-sri-lanka/

3. Aviation, M. o. (2019). Statistics. Ministry of Transport \& Civil Aviation.

4. Ismail, A., \& Yunan, Y. (2016). SERVICE QUALITY AS A PREDICTOR OF CUSTOMER SATISFACTION AND CUSTOMER LOYALTY. Scientific Journal of Logistics , 269-283.

5. Khan, M., Batool, I., \& Hussain, S. (2015 ). Customer Satisfaction at Public Sector: A Case Study of Pakistan Housing Authority. Pakistan Journal of Social Sciences , 1038-1050 .

6. Naik, C., Gantasala, S., \& Prabhakar, G. (2010 ). Service Quality (Servqual) and its Effect on Customer Satisfaction in Retailing. European Journal of Social Sciences , 231-243.

7. Preko, A., Feglo, M., \& Agbanu, S. (2014 ). Service Delivery, Customer Satisfaction and Customer Delight in the Real Estate Business. Evidence from Elite Kingdom Investment and Consulting Company Ghana . European Journal of Business and Management , 71-83.

8. (2018). Registered Finance Leasing Establishments. Central Bank of -Sri Lanka.

9. Sekaran, U. (2003 ). Research Methods for Business: A Skill Building Approach. Hokoben : John Wiley \& Sons, Inc.

10. Seth, N., Deshmukh, S., \& Vrat, P. (2004 ). Service quality models: a review. International Journal of Quality \& Reliability Managemen , 913-948.

11. Shahin, A. (2013). SERVQUAL and Model of Service Quality Gaps:A Framework for Determining and Prioritizing Critical Factors in Delivering Quality Services. .

12. Yarimoglu1, E. (2014). A Review on Dimensions of Service Quality Models. Journal of Marketing Management , 79-93.

13. Zaid, M. A. (2015). Correlation and Regression Analysis. Ankara: ORGANISATION OF ISLAMIC COOPERATION STATISTICAL ECONOMIC AND SOCIAL RESEARCH AND TRAINING CENTRE FOR ISLAMIC COUNTRIES. 
INTERNATIONAL JOURNAL OF ACADEMIC RESEARCH IN BUSINESS AND SOCIAL SCIENCES

Vol.9, No. 1, Jan, 2019,E-ISSN:2 22 2-6990 @ 2019 HRMARS

14. Zengmo, M., Laimpreecha, W., \& Chemsripong, S. (2015). The impact of Service Quality of Customer Retention in Airline Industry of Bhuthan . International Business Management, 1281-1284 . 